\title{
Profit Distribution and Compensation Structures in Publicly and Privately Funded Hybrid Venture Capital Funds
}

\author{
Mikko Jääskeläinen ${ }^{\text {a1 }}$ \\ Markku Maula ${ }^{a}$ \\ Gordon Murray ${ }^{b}$
}

${ }^{\mathrm{a}}$ Institute of Strategy and International Business, Helsinki University of Technology, PO Box 5500, 02015 HUT, Finland

${ }^{b}$ School of Business \& Economics, University of Exeter, Streatham Court, Rennes Drive,

Exeter, EX4 4PU, UK

Research Policy, in press

University of Exeter

Discussion Papers in Management

Paper number 07/04

ISSN 1472-2939

${ }^{1}$ Corresponding author, Tel: +358 9451 3086; Fax: +35894513095 email: mikko.jaaskelainen@tkk.fi 


\title{
Research Policy, in press
}

\section{Profit Distribution and Compensation Structures in Publicly and Privately Funded Hybrid Venture Capital Funds}

\author{
Mikko Jääskeläinen $^{\text {a } 1}$, Markku Maula ${ }^{\text {a }}$, Gordon Murray ${ }^{\text {b }}$ \\ ${ }^{a}$ Institute of Strategy and International Business, Helsinki University of Technology, P.O. \\ Box 5500, 02015 HUT, Finland \\ ${ }^{b}$ School of Business \& Economics, University of Exeter, Streatham Court, Rennes Drive, \\ Exeter EX4 4PU, UK
}

\begin{abstract}
Policy makers have become increasingly concerned at the lack of risk capital available to new and early stage entrepreneurial ventures. As a public response to a perceived market failure, several governments have set up programs to channel equity finance to capital constrained but high potential, young enterprises. Critically, government support is often directed through the agency of private venture capital funds. We examine the profit distribution and compensation structures used in these hybrid public/private funds. We appraise government policy makers' ability to use these structures to improve the expected returns in market failure areas in order to attract private sector investors and professional managers to participate in these funds. The results derived from our simulation study suggest that such asymmetric profit sharing models can only resolve relatively modest market failures unless the programmes also manage to attract highly competent investors who are able to produce above average gross returns in market failure areas.
\end{abstract}

Keywords: venture capital, distribution structures, compensation structures, hybrid funds, enterprise policy

\footnotetext{
${ }^{1}$ Corresponding author, Tel: +358 9451 3086; Fax: + 3589451 3095, e-mail: mikko.jaaskelainen@tkk.fi We would like to acknowledge the financial support from the TEKES, the Finnish Funding Agency for Technology and Innovation (grant \#404/38/03). Mikko Jääskeläinen also acknowledges financial support from the research foundation of the OP-group. We are indebted to Sean Finucane, Albert Schultz, and participants of the Babson Kauffman Entrepreneurship Research Conference 2004 in Glasgow for their valuable comments and suggestions on early drafts of this paper as well as Richard Marriott for his contributions to the modelling that provided the basis for the model developed in this paper. We would also like to acknowledge the helpful comments from the editor and two anonymous reviewers of Research Policy.
} 


\section{Introduction}

Over the last decade, governments around the world have increasingly channelled public financing to high potential, new ventures through private sector venture capital (VC) firms (Armour and Cumming, 2006; Da Rin et al., 2006; Leleux and Surlemont, 2003; Lerner, 2002; OECD, 1997). These vehicles by which independent venture capital firms are used to channel and allocate public financial support are termed ‘hybrid funds' (OECD, 1997).

The existing body of knowledge has two shortcomings from the perspectives of policy makers facing the decision of how to best structure such funds to attract competent private sector financers and managers. First, several alternative mechanisms have been deployed in numerous countries, and as a result, the characteristics and results of these interventions are obscured by the diversity of underlying structures, idiosyncrasies of the national institutional environments, and the specific time periods at which they were active. Although there are multiple studies on publicly supported venture capital programs, these analyses mostly operate at a country specific level (e.g. Ayayi, 2004; Avnimelech and Teubal, 2006; Dossani and Kenney, 2002; Lerner, 1999, Cumming, 2006, Cumming and MacIntosh, 2006). Where international comparisons are attempted (OECD, 1997; Modena, 2002; Gilson, 2003; Maula and Murray, 2003; Lerner et al., 2005), the conclusions are necessarily highly qualitative. Coherent and generic policy comparisons of cause and effect remain very difficult to make.

Second, the venture capital literature addressing the structuring of funds has approached the issue as primarily a private sector activity. While the structuring of a venture capital fund has been analysed from several perspectives, including the compensation and incentives of fund managers (Cooper and Carleton, 1979; Gompers and Lerner, 1999; Schmidt and Wahrenburg, 2003), the structuring of fund agreements (Brophy and Haessler, 1994), the structures of relationships (e.g. Sahlman, 1990; Wright and Robbie, 1998), and the use of covenants in venture partnership agreements (Gompers and Lerner, 1996), these studies 
typically assume that all limited partners (LPs) invest on equal terms (i.e. pari passu).

Therefore, in these previous studies, both general (GPs) and limited partners are seen to have the specific and exclusive goal of maximizing their net capital gain over the life of the fund.

This earlier research, while valuable, becomes insufficient when different classes of LP with different objectives are introduced. On the one hand, when assessing the characteristics of individual programs at a point in time, little can be seen as generalisable to the behaviour and effectiveness of fund structures. On the other hand, when considering the relationship between the limited and managing partners, extant research does not accommodate the situation where one of the limited partners has other goals that take precedence over the maximizing of an economic return on investment. Given the rapidly increasing international popularity of hybrid fund activities as a means of addressing 'financing gap' issues (Maula and Murray, 2003; OECD, 1997, 2006), there is an urgent need to understand the impacts of the different design parameters of these novel publicly and privately funded hybrid venture capital funds.

We address this research gap by providing an examination of the frequently used structures for profit distribution (to the LPs) and compensation (of the GP) employed in hybrid venture capital funds. In this paper, we examine the following three aspects of these fund structures. First, from the LPs’ perspective, we examine how different profit distribution structures alter the expected net returns for private investors across a range of expected portfolio gross return levels. Second, from GP's perspective, we analyse how the components of compensation structure alter the expected net compensation of the GP for a range of expected portfolio gross return levels. Finally, we address the interactions and particularly the limits of the distribution and compensation structures in increasing the incentives for private actors to participate in hybrid funds. 
We approach the problems of idiosyncrasy and comparability by utilizing a simulation methodology. First, we derive a representative set of profit distribution and compensation structures from our examination of existing hybrid funds. We then build a simulation model of a typical early-stage hybrid fund in order to examine how these different structures affect the expected returns to the participating limited and general partners from the private sector. We focus on how the structures per se influence the distribution of profits among LPs and compensate the GP, in a range of gross portfolio return levels. Although we do not seek to explain the overall investment performance of the programs utilizing these structures, the analysis of the limits of the profit sharing models to boost net returns for given gross returns has important implications for the design of such programs.

Our results indicate that the ability of the examined structures to boost the net returns and thereby create incentives for commercial participation of LPs and GPs is limited in circumstances of low expected fund returns. The largest discrepancy in expected fund performance in terms of IRR (i.e. difference between the ex ante expectations of both management and investors on the performance of the hybrid fund when compared to a private VC fund investing in a functioning market) that can be effectively accommodated by the government supported structures is between 5 and 9 percentage units. The actual point at which these leveraged structures fail depends on the LPs' and GP's opportunity costs. While there are circumstances when the examined structures do succeed in creating incentives for private sector actors to participate in publicly funded hybrid funds, the applicability of these mechanisms is limited to relatively modest levels of market failure unless the programs manage to attract highly competent investors who can produce above average gross returns in market failure areas. ${ }^{1}$

\footnotetext{
${ }^{1}$ Although there is little empirical evidence on the effects of different profit sharing models on the quality of investors attracted, several more successful government programs have explicitly targeted the entry of new professional teams in the early stage market. These programs have used upside incentives that are supposedly more attractive for the most competent investors including an open bidding process and professional due
} 
The rest of the paper is organised as follows: First, we review existing profit distribution and compensation structures targeted at private sector investors and managers in these hybrid funds and examine the policy logic of using venture capital as a support mechanism for the financing of high potential young firms. Second, we present our model and outline its operationalisation by reference to a generic, early-stage venture fund. Third, we provide a description of the results of a simulation of this model. Finally, we conclude by discussing the implications and importance of our findings for both theory and practice.

\section{Existing and past hybrid fund structures}

\subsection{Governments' motivation for involvement in venture capital markets}

Although the primary role for governments in developing a functioning venture capital market is considered by venture capital practitioners, as well as many scholars, to be restricted to the creation and maintenance of conducive fiscal and legal environments for VC financing (Armour and Cumming, 2006; Da Rin et al., 2006; European Commission, 2001, 2005; EVCA, 2004; Gilson, 2003; Maula and Murray, 2003; OECD, 1997, 2004), there is a strong and widespread 'belief'² by many national governments of the necessity for pro-active actions to support the emergence and operation of national venture capital industries. ${ }^{3}$ Government support for venture capital markets is often motivated and legitimized both by a perceived ‘market failure’ or 'financing gap’ that is experienced by early stage ventures (Cressy, 2002;

OECD, 2006) and by the positive impact that venture capital is seen to have a on job creation, innovation, and economic growth (Achleitner and Klöckner, 2005; Alemany and Martí, 2005; Engel and Keilbach, 2002; Florida and Kenney, 1988; Kortum and Lerner, 2000; Lerner,

\footnotetext{
diligence process. Examples of such programs include Israeli Yozma (Avnimelech et al., 2006), Innovation Investment Funds program in Australia (Cumming, 2006), New Zealand Venture Investment Fund program (Lerner et al., 2005), and most recently the Enterprise Capital Funds program in the United Kingdom.

${ }^{2}$ The term 'belief' is used advisedly. Arguments for government involvement are often based on the example of the US. They very rarely include any econometric estimations as to the shortfall of investments or the welfare benefits of proposed programs.

${ }^{3}$ E.g. Lerner et al. (2005) state:”It is instructive to observe that all venture capital markets of which we are aware were initiated with government support."
} 
2002; Romain and van Pottelsberghe, 2004; Williams, 1998). Although the evidence in the literature on the existence of financing gaps as well as on the effect of venture capital on economic growth is still developing, there has been nevertheless a significant growth across several developed countries in government supported structures targeted at facilitating risk capital investments to new, high potential enterprises.

In order to correct for perceived supply-side failures in domestic VC markets, several countries have set up governmental VC organizations to invest either directly in nascent and young ventures or indirectly as a limited partner in specialist VC funds focused on young entrepreneurial ventures. Yet, state controlled investment programmes with civil servants identifying and supporting national champions via direct and preferential investment activities is now viewed with considerable circumspection. The practice of governments attempting to 'pick winners’ at a firm level has been largely discredited (Avinimelech and Teubal, 2006; Gilson, 2003; Modena, 2002; OECD, 1997, 2004; Wessner, 2002). Similarly, direct involvement in new venture investment by government agencies carries a material risk of market disruption through the potential misallocation of capital and the consequent 'crowding out' of private investors (Armour and Cumming, 2006; Cumming and MacIntosh, 2006; Leleux and Surlemont, 2003).

Accordingly, the involvement of commercially motivated, private sector investors acting as 'agents' on behalf of government 'principals' has now become the predominant modus operandi. These indirect public investments are done with the state's involvement being subordinate to the executive actions of experienced private sector investors including venture capital GPs. However, if the public investor wishes to utilise a venture capital GP to channel funds to an area with a perceived market failure, a hybrid structure where the private and public sector investors invest under identical conditions may be unattractive for the private 
investors. ${ }^{4}$ Such a pari passu arrangement does little to alter expected outcomes that led to the supply side, market failure in the first place. Thus, the involvement of the GP and any private sector LPs in the fund will require the engineering of more attractive profit expectations in order for them to be willing to participate (Avnimelech and Teubal, 2006; Gilson, 2003;

Hirsch, 2006; Maula and Murray, 2003; Murray and Marriott, 1998).

\subsection{Profit distribution structures for the limited partners}

Given considerable experimentation to find effective prescriptions, the structures of the publicly and privately funded hybrid vehicles vary markedly by country. In discussing the evolution of different profit distribution structures in government's support of venture capital, it is important to acknowledge the contribution of the Small Business Administration of the US government. Specifically, the Small Business Investment Company (SBIC) scheme which started in 1958 has become an important benchmark program. ${ }^{5}$ This basic model of an 'equity enhancement' program by which the state's involvement (either by direct investment or acting as a guarantor to other fund raisers) enables additional and cheaper funds to be raised thereby creating a leverage advantage to private investors - has been reflected in programs world-wide (see Figure 1). For example, the current activities by the UK government in devising the Enterprise Capital Fund program to provide growing businesses with individual equity financings up to a $£ 2$ million ceiling is a local interpretation of the SBIC model (HM Treasury \& Small Business Service, 2003).

Table 1 illustrates the main types of investment structures that have been used to facilitate the development of an early stage, venture capital industry. While the most used structure is the one that involves no asymmetric profit distribution between public and private LPs, there

\footnotetext{
${ }^{4}$ At best, public money invested pari passu can increase the size and scale efficiencies of the fund but at the cost of introducing a limited partner with often widely different interests to the other investors.

${ }^{5}$ Over the period 1959 - 2002, the SBIC program helped raise $\$ 37.7$ billion directed to some 90,000 businesses (US Small Business Administration, 2003). The program represented 8\% of total US venture capital dollars and $64 \%$ of US seed capital financings in the eight years 1994 to 2002. Importantly, less than \$10 billion of the finance raised came from SBA guaranteed funds (US Small Business Administration, 2003)
} 
are several structures that aim to enhance the expect returns of private LPs by alterations to the distribution of profits, timing of investments, down-side protection, and the payment of fund operating costs.

Insert Table 1 approximately here

Based on the effects of these structures on the profit distribution between private and public LP, they can be classified in four generic categories:

1. Differential timing of the investment 'draw downs' of public and private investors. The public funds are drawn down first, followed by the private funding. This earlier commitment of public funds shortens the duration of the private investors' investment and thereby increases the private LPs' internal rate of return.

2. Leveraging the returns to private investors with debt. Structuring the government participation as a loan creates a leverage effect that increases the private LPs profit when the IRR of the fund exceeds the interest rate on the debt.

3. Capping the profits entitlement of the public investor. This structure increases the relative share of any surplus that the private investors receive. This has been realised by limiting the profits for the public investor and/or by providing private investors with an early buy-out option of the (successful) fund.

4. Guarantee of compensation to the private investor for loss of invested capital. A guarantee from the public investor, rarely above $75 \%$ of the private investors' total loss, provides a degree of 'down-side protection' by an unequal sharing of the costs of unsuccessful investment outcomes. As a sole component, such schemes protect rather than reward investors by reducing the penalty of poor decision making. In so doing, they create a moral hazard. Guarantees are usually an additional element to a hybrid fund program.

We illustrate and analyse this categorization with the results from a VC fund simulation. 


\subsection{Compensation structures for the general partner}

Government-assisted venture capital programs are predominantly designed to encourage additional equity finance for new or young, high potential ventures. While the involvement of private investors increases the available financial resources, their allocation to attractive new ventures requires substantial expertise, industry knowledge and effort by the professional managers (GPs) of these VC funds. Although the investors in a fund can also occasionally act as its manager, e.g. in a bank-owned 'captive’ VC fund, these roles are typically separated.

The venture capital industry is predominantly structured as limited liability partnerships (LLPs). Investors become limited partners and venture capital managers are the general partners of the fund (Fenn et al., 1995; Sahlman, 1990). In a typical LLP, the general partner effectively holds complete control over committed funds and the investment process of the partnership. The investors are legally constrained from a direct involvement in the operation of the fund in order to secure preferential tax advantages. Thus, full autonomy over investment activity is given to them despite the general partners typically providing no more than $1 \%$ of the fund's total committed capital (Gilson, 2003; Sahlman, 1990; Schmidt and Wahrenburg, 2003).

While the GP acts as a professional intermediary mitigating the inherent uncertainty, asymmetric information, and agency costs that would arise if institutions invested directly in

new ventures (Amit, et al., 1998; Barry, et al., 1990; Bergemann and Hege, 1998; Megginson and Weiss, 1991), the contractually defined, non-involvement role of limited partners introduces the same conflicting interests between the general and limited partners. The resulting problems of moral hazard and self-interested behaviour are addressed by ex ante contractual measures and by compensation structures that are strongly incentivising to fund managers. 
To align the interests of LP and GPs, in a typical fund structure the compensation of the GP is highly dependent on the commercial success of the fund. The GP typically receives of a 20\% share of the net capital gain of the fund (Litvak, 2004; Sahlman, 1990; Schmidt and Wahrenburg, 2003). This participation by the GP in the investment returns is known as 'carried interest'. Before being allowed to participate in any capital distribution, GPs are often contractually required to return the LPs' total drawn-down capital with a minimum agreed level of interest, i.e. the 'hurdle rate’ (Gompers and Lerner, 1999; Schmidt and Wahrenburg, 2003). Once the hurdle is met, the GP ‘catches up’ the distributed profits of LPs by receiving all of the capital gains until the agreed carry ratio has been reached. In addition to these capital gain incentives, the GP usually receives an annual management fee of approximately 2 - 21/2\% of the total committed capital of the fund (Schmidt and Wahrenburg, 2003). This fee is primarily levied to cover the agent's costs in operating the investment activities of the fund. It is not intended by the LPs to be seen as a significant and separate source of profit for the managers. ${ }^{6}$ Thus, the fee income to the GP may often taper towards the end of the fund's fixed life in order to reflect the gradual lessening of activity by the GP.

When a government supported venture capital program seeks to use private sector fund managers in order to invest in a market area or investment stage with traditionally unattractive returns, the GP faces a similar situation to the private sector LPs. If the compensation structure is identical to those of venture capital funds operating at other (later) stages of the investment cycle, the returns to the management partners of a governmental program are likely to be lower. This is particularly the case given that the targeted early-stage investments frequently employ smaller funds (i.e. lower fee incomes) and yield lower returns (i.e. a smaller 'carry') as found by Murray and Marriott (1998). Thus, the typical private sector structure will not be attractive in these challenging circumstances. If significant changes are

\footnotetext{
${ }^{6}$ However, the annual fees rates to GPs have appeared remarkably insensitive to the growth of funds under management over time thereby creating a significant source of net income to managers (Zider, 1998, Gompers and Lerner, 1999).
} 
not made to skew the risk reward trade-off there is a real danger of the adverse selection of less experienced venture capitalists with lower opportunity costs.

\section{Simulation Model}

\subsection{Objectives and organisation of the model}

As noted, it is difficult to compare and contrast the effects of existing structures because of the idiosyncratic character of individual programs and their contexts. Therefore, we construct a simulation of an archetypical investment process undertaken by a generic, earlystage venture capital fund. This model is used to study the effects of profit distribution and compensation structures on the expected returns of limited and general partners, respectively.

Our interests are directed towards three defining questions:

1. Firstly, how do the different profit distribution structures alter the scale and allocation of returns to private and public limited partners? That is, do the structures create sufficient incentives for the private sector institutional investors to participate in markets that would otherwise be commercially unattractive?

2. Secondly, what are the roles and effects of carry, hurdle rate and catch-up in the typical compensation structure of the general partner? How can the compensation structure be altered and what are its limits in increasing expected compensation?

3. Finally, how do the profit distribution between private and public limited partners and compensation of general partners interact? Can such structures be designed that would maintain the incentives to participate for both the LPs and the GP in an environment of low investment returns?

We study these question with a stochastic simulation employed to model the investment activity of an early stage VC fund. We use a simulated investment process to model the performance of a fund that consists of up to 15 portfolio investments. The development of each venture is modelled with a three level scenario tree, each level corresponding to one of 
three sequential investment rounds in the venture. At each node of the tree, the venture capitalist assesses the profitability of the investment based on the expected outcomes. To examine the effect of these structures on the distribution of rewards between different partner types, we simulate the outcomes of 250 of these funds under a range of expected return levels. The components of the simulation and the parameters are detailed below. A summary of the parameters is provided in Table 2.

Table 2 approximately here

\subsection{Investment process}

We give the venture capital fund a fixed life of ten years, i.e. the standard industry arrangement (Sahlman, 1990). In order to ensure a sufficient period for the development of the portfolio firms, we assume an investment window lasting for the first four years of the life of the fund. Investments in the fund's portfolio arrive at equally spaced intervals over this period. Each investment has the opportunity, dependent on performance, of two additional investment rounds and an exit (sale or abandonment) from the fund. With two years between rounds, each investment can be held maximum of six years in the portfolio.

At each round, the GP assesses the venture according to its expected outcomes and makes a 'go/no go' decision whether or not to continue to finance the portfolio firm (Gompers, 1995). The decision is based on whether or not the expected returns from the focal investment exceed the required return set for the fund. As we are examining government backed hybrid funds investing in market failure areas, we recognise that the funds have goals beyond the maximizing of commercial returns. Thus, we assume that these funds do not have a return requirement that would fully match risk-adjusted returns from alternative investment targets. However, we limit our analyses to situations where investments are made in ventures that are expected to return at least the capital invested, i.e. the required return is effectively nonnegative. 
When the venture reaches the exit phase after a maximum of three rounds of finance, the investment is liquidated and the residual value is returned as cash directly to the LPs of the fund. Once the stipulated hurdle return rate is met for the drawn-down finance, the general partner also participates with the limited partners in any further distributions at the agreed ratio of the carry. Standard industry practice replicated by our model is that, after achieving the hurdle rate of return, the GP receives all future capital gains up until the point at which its share of the existing capital gain of the fund reaches 20\% (Gompers and Lerner, 1999; Schmidt and Wahrenburg, 2003). From this time on, all future returns are shared 80:20 between the LPs and GP, respectively (Gompers and Lerner, 1999). After all the portfolio investments are liquidated, either via a market exit or by project abandonment within the fixed duration of the fund, the cumulated net capital gains are calculated for all parties.

\subsection{Portfolio companies and scenarios}

We design the portfolio of the venture capitalist to consist of 15 identical early-stage investments, following the example and parameterisation of Murray and Marriott (1998). The development of a new venture is simplified to three stages corresponding to the initial financing on entering the portfolio and two follow-on investment rounds. At the end of each investment period, the venture has four development outcomes expressed as a multiple of the change in the value of the venture over the preceding two years. In total, the scenario structure results in a maximum of 64 different outcomes (i.e. $4^{3}$ ) after the third stage. The terminal value of the venture is determined by the success of each investment round as the portfolio firm moves from stage to stage over the six year period. This portfolio development is randomised using VC industry estimated probabilities for each of the four investment outcomes over each of the three consecutive financing stages. 


\subsection{Expected market situation}

The expected outcomes from an investment are determined both by the success of the venture while in the portfolio and by the prevailing conditions of the exit market once the GP seeks to liquidate its investment. To combine both these characteristics and to obtain a realistic distribution for the venture values, we first calculate indexed values for the ventures and then link them to exogenously adjusted market levels.

To obtain the terminal values, we use the value multiples provided by Murray and Marriott (1998) from an international survey (Europe/US) of the early-stage venture capital industry. These multiples provide the distribution for the potential terminal values of the ventures at the last (third) stage. To link this distribution to exogenously adjusted market levels, we convert these absolute values to a relative index using the highest possible outcome as a benchmark. This scales the 64 outcomes to relative values between zero and one. We then link these relative values to market values that correspond to the given return level. This gives us a means to control the expected return level exogenously, still maintaining a realistic distribution of outcomes for an individual investment.

\subsection{Alternative profit distribution and compensation structures}

The fund structure consists of two distinctive parts: the compensation of the GP and the profit distribution between public and private LPs. To define the GP's compensation structure, we use an industry standard structure (Gompers and Lerner, 1999; Sahlman, 1990). The GP receives an annual management fee of $2 \frac{1}{2} \%$ of the committed fund size and is rewarded with a $20 \%$ share of the fund's net capital gain (with catch-up) after achieving an annualised hurdle return to the LPs of 5\% for the drawn-down funds. As noted, it is assumed that the fee income only covers operational costs and does not constitute a significant source of profit for the GP. For a small, early stage VC fund, this is an entirely realistic assumption. Further, GPs are themselves required to provide an investment of $1 \%$ of the fund size (Gilson, 
2003; Gompers and Lerner, 1999; Sahlman, 1990). We start from this standard structure but vary the parameters as we proceed with the analysis.

For the profit distribution between the private and public investors (LPs), we use four alternative distribution structures with each compared against a benchmark structure. In the standard, private sector, venture capital fund structure, all LPs invest on equal terms (pari passu) with no distinction between private and public investors. We use this model as a benchmark in order to study how the profit distribution is altered when we change this structure:

LP structure $1 \quad$ Investments are timed so that government invests first followed by the private investors.

LP structure $2 \quad$ Government investment is provided as a loan with fixed interest level (5\% p.a.) and preferred payments. ${ }^{7}$

LP structure $3 \quad$ The total profits of government are capped at a predetermined level (of $5 \%$ p.a.). ${ }^{8}$

LP structure $4 \quad$ Government provides a down-side guarantee covering $75 \%$ of any capital losses of private investors.

Each of the four structures is independently applied in the simulation. That multiple distribution structures are used simultaneously in extant programmes is recognised by the authors. However, it is important initially to determine the contribution of individual structures before testing more complex combinations. Table 3 summarises the tested structures of general and limited partners.

\footnotetext{
${ }^{7}$ We use $5 \%$ to approximate the long-term risk-free return rate. See the analysis below for the sensitivity considerations of this parameter choice.

${ }^{8}$ See footnote 6 .
} 
Table 3 approximately here

\section{Findings}

To examine the differences in the profit distribution structures (LPs) and the effects of the compensation structure (GP), we simulate the investments and outcomes of a venture capital fund under each structure and analyse the ensuing returns and compensation for the private limited partners, the public limited partner and the general partner. To compare the profit distribution characteristics of the structures, we simulate for each structure the terminal performance of 250 random funds, under a range of gross return levels. ${ }^{9}$

Our study is based on the premise that the governments seek to attract private investors to invest and competent venture capitalists to manage funds in problematic markets. Given this assumption, the LPs and GPs targeted have an opportunity cost that is defined by the alternative compensation that they can receive from managing and investing in funds operating in more attractive risk capital markets. Thus, in order to study how the existing compensation structures function in creating incentives for private sector actors to participate in supposedly high risk/low return markets, we compare how effectively the structures help maintain the compensation and returns of GPs and LPs, should the expected return levels be lower than that provided by their opportunity costs.

The opportunity costs of the private sector actors will vary across countries due to differences in both the national, investor return levels as well as institutionalised practices influencing the compensation of GPs. Accordingly, we present our analyses and results for a continuum of opportunity costs. However, for the sake of presentation, we illustrate the effectiveness of the structures to maintain expected returns, and we elaborate the consequences using a single reference point against which we compare the structures. To

\footnotetext{
${ }^{9}$ We use the same 250 randomized funds with all market levels and incentive structures. The number of simulated funds is restricted by the feasibility of computationally heavy modelling. However, with 250 observations, the confidence interval for means at the confidence level of $95 \%$ is approximately $\pm 1 * 10^{-4}$, which we consider to be sufficient.
} 
select a representative reference point or benchmark, we assume that the expected average return from the available alternative funds equals the European annualised pooled returns to all private equity, i.e. a long run return of 9.5\% (EVCA, 2005). While this choice of a single opportunity cost is somewhat arbitrary, our results are not constrained by this illustrative device.

In addition, we differentiate between the gross returns from the underlying portfolio and the net returns to the investors after the costs of GP's carry and fee. While typically the returns from VC funds are expressed in terms of net returns ${ }^{10}$, we compare both the LPs' net returns and GP's compensation against the gross returns from the portfolio of investments. This allows us to better explain the distribution of returns of a fund. We differentiate between these types of returns by using terms 'net returns' to refer to returns for LPs, and 'gross return' to refer to the return from the portfolio of investments without costs subtracted.

\subsection{Division of returns between investors}

\subsubsection{Characteristics of the profit distribution structures}

Figure 2 presents the results of the simulation of the return profiles for each of the four alternative profit distribution structures compared with the pari passu model. The horizontal axis presents the pooled returns from the simulated portfolios. These are the gross returns from the portfolio before subtracting any management costs. The vertical axis represents the net return to the limited partners after the management costs and GP compensation have been deducted. For each structure, the black lines present the returns for private (solid line) and public investors (dashed line). These are contrasted to the equivalent returns of the pari passu

\footnotetext{
${ }^{10}$ The exact meaning or the returns to a VC fund is not a trivial issue. Returns are often expressed gross, net, on theoretical valuation guidelines or on the results of cash to cash realised transactions. It is not easy in practice to determine the real performance of a extant VC fund.
} 
model (grey line) to illustrate the effects of the asymmetric structures on the subsequent profit distribution. $^{11}$

Insert Figure 2 approximately here

We observe the four LP structures to have differing effects on the profit distributions. First, the asymmetric timing of the cash flows of private and public investors (LP structure 1) produces an apparent lateral shift improving the profits of the LPs. The shorter investment period of private investors increases their internal rate of return, while the correspondingly prolonged investment period for the public investor has the opposite effect. However, the shorter investment period also emphasises the effect of losses. Structure 1 results in larger losses to private LPs than to the public investor should the fund perform poorly enough.

Second, in the structure where the government's share of capital is provided as a fixed rate loan (LP structure 2), the change in the profit distribution is characterised by the leverage effect. As the return to the public investor is constant at all return levels, the private investors' outcome is higher than the pari passu return when the portfolio returns are higher than the cost of the debt. Similarly, the returns to private investors are lower than that of the public investor when the fund returns are lower than the interest charged on the government's loan.

While the two structures above alter the profit distribution across all return levels, the capping of government returns (LP structure 3) and the guarantee (LP structure 4) have only a partial effect on the profit distribution. The profit cap restricts the government returns to a pre-specified level, thus increasing the return to private investors when fund returns exceed this level. The guarantee effects the profit distribution only where the invested capital is partially or wholly lost, i.e. effectively with IRR levels below zero. In this case, the losses of private investors are reduced as government covers them to a pre-specified proportion.

\footnotetext{
${ }^{11}$ Should the level of the hurdle differ from the $5 \%$ that is used here as an example, the horizontal step caused by the hurdle in the return profile moves either towards the upper right corner with higher hurdle or to lower left corner with a lower hurdle
} 


\subsubsection{Effectiveness of the profit distribution structures}

The differences observed in the effects of the LP structures mark also differences in the ability of the structures to increase the private LPs' expected returns when the fund invests in early stage markets with a high probability of low returns. In Figure 2, the effectiveness of the structures in increasing the expected returns of private LPs in is analyzed using European average return as a point of reference.

In each section of Figure 2, point A marks the European benchmark return. Under a pari passu structure, this benchmark return of $9.5 \%$ net, requires a gross return of portfolio IRR of $11.3 \%$, the difference of 1.8 percentage units illustrating the impact of the running costs of the fund including the compensation of the GP. The point B indicates the expected gross return required to produce the benchmark net return (9.5 \%) to the private LPs, when one of the examined distribution structures is used. For example, with the staged cash flows (LP structure 1), the private LPs earn IRR of 9.5\% when the expected gross return from the portfolio is $2.9 \%$. For the loan structure and the structure with capped public LP returns, the corresponding gross returns are $9.4 \%$ and $8.7 \%$, respectively. The guarantee model (LP structure 4) does not alter the expected returns on these return levels.

Thus, it appears that the structure with asymmetric timing of government and private investments (LP 1) is the most effective of the modelled alternatives in improving the returns to the LPs, i.e. helping private investors meet their opportunity cost. The two models where government loans the fund its share of capital or caps its own share of profits produce nearly identical results. Given the leverage effect, both increase performance mainly at the upper end of expected fund returns. They provide only a slight enhancement of returns to the private investors at lower return levels. $^{12}$

\footnotetext{
12 If we assumed that both the interest on the loan and the government return cap were $0 \%$, which would produce the largest leverage for the private investor in these models (assuming that the initial capital is returned to government), this would lower the sustainable expected gross return level to $7.4 \%$ (for loan structure) and $6.5 \%$ (for profit cap structure).
} 


\subsection{The compensation of the general partner}

\subsubsection{Effects of the components}

Figure 3 reports the results of the simulations which test the specific effects of the hurdle, catch-up, and carry on the compensation of the GP. The figure presents the GP's median compensation for different compensation structures as a percentage of the benchmark compensation. The benchmark for the GP's compensation is defined as the expected compensation from a fund with expected net return on 9.5\% using the standard compensation structure for a GP (i.e. 1\% total partner investment in fund, hurdle rate of 5\%, catch up, a carry of $20 \%$, and a pari passu structure for LPs). We calculate the net present value of the expected cash flows of the GP for the alternative structures and compare them against this benchmark opportunity cost. ${ }^{13}$ Point “A” marks this benchmark level of compensation.

Insert Figure 3 approximately here

The development of the GP's compensation as the function of the gross returns of the portfolio follows the expected form. The carried interest starts to increase the expected compensation when the gross returns exceed the hurdle rate. After this point, the compensation approaches rapidly the levels of the compensation offered by a structure where the hurdle rate is ignored. Due to the catch-up, the nominal compensation is ultimately identical on higher performance levels with and with-out the hurdle. The difference between the two is solely due to the difference in net present values occasioned by the timing of the cash flows. The better the performance of the portfolio, the smaller this difference becomes.

Therefore, when compared to the benchmark (point “A”), the structure that ignores the hurdle rate provides only a modest increase in the compensation of the GP, thus allowing only

\footnotetext{
${ }^{13}$ The chosen discount factor (20\%) affects the relative weights of the initial investments and the carried interest. As a result, the lower the discount factor, the higher the expected compensation and, accordingly, the further to the left of the chart the compensation curves are placed. However, as the timing of the cash flows does not change between the compensation alternatives, the relative changes between different compensation structures are small with respect to the discount factor. See the footnote 15 for details on the effects of the discount factor on the results.
} 
a small decrease in the expected gross returns in order to maintain the incentives to participate (point "B”). This reduced effect is due to the catch-up provision, as without the catch-up, the expected compensation of GP would be significantly lower, as demonstrated by the line labelled "no catch-up”.

It appears that the most effective way to increase the compensation of the GP is to alter the carry ratio. Figure 3 present a hypothetical structure that has a carry ratio of $100 \%$ and has no hurdle. In this case, all the profits of the fund a fund are directed to the GP, thus providing the highest possible compensation level. This extreme structure provides the benchmark compensation to the GP with the expected gross returns of $3.1 \%$. This is the lowest level of fund performance at which the GP's compensation can be maintained with the given opportunity cost.

\subsubsection{Limitations of the carry compensation}

A carry ratio of $100 \%$ is obviously unrealistic as it implies that LPs would agree only to have their capital returned. When the disparity between the opportunity cost and the expected portfolio return is small, a lower increase in carried interest is sufficient to maintain the GP's level of compensation. Figure 4 presents the result from the simulations reporting, for a given market level, the required carry ratio that maintains the compensation of the GP at the level of its opportunity cost. The results are reported as a set of indifference curves, for which the compensation of GP is held constant. The decreased compensation resulting from lower expected portfolio returns is compensated with a higher carry to the GP. ${ }^{14}$ These indifference curves are reported for a set of opportunity costs, marked with the corresponding expected gross returns.

\footnotetext{
${ }^{14}$ In practice, carried interest percentage is toughly negotiated and unlikely to exceed 30\% (see e.g. Gompers and Lerner, 1999, Schmidt and Wahrenburg, 2003, and Litvak, 2004). However, this analysis is made in order to show the theoretical limits of the compensation structures.
} 
Insert Figure 4 approximately here

Increasing the carry ratio offers a means for increasing the compensation of the GP at modest levels of performance discrepancy. The higher the opportunity cost (i.e. the higher the expected gross return from the portfolio), the higher is the amount of profits in absolute terms. Therefore, a relatively modest increase in the carry ratio is sufficient to compensate the GP for decreased expected returns. However, the lower the levels of expected returns, the less the fund generates in absolute terms. Accordingly, with low opportunity costs, the carry ratio required to maintain the compensation rapidly approaches $100 \%$. For the benchmark case, the line marked as " $11 \%$ ” in Figure 4 presents the set of required carry ratios. As the expected gross returns decrease, the carry required to maintain the compensation increases along the curve until it reaches a limit when all profits are directed to the GP. This point, where expected gross returns are $3.1 \%$, is marked with point “C” (corresponding to point “C” in Figure 3). ${ }^{15}$

\subsection{Interaction and limits of the profit distribution and compensation structures}

The analyses above have demonstrated how the returns and compensation of the LPs and GP are affected by different types of profit distribution and compensation structures. So far, the analyses have treated investors and managers separately in order to illustrate the effects of the mechanisms. However, given our premise that the governments are interested in involving private actors as both investors and managers in hybrid funds, we next examine if the returns and compensation of the both parties can be maintained simultaneously. Additionally, we present the results for a continuum of opportunity cost, in contrast to the fixed benchmark utilized in the analyses above. It is important to note that in the analyses below, we model only the expected direct costs of GP compensation. Thus, the analyses do not consider the

\footnotetext{
${ }^{15}$ To illustrate the effect of GP's discount factor on the results presented above, we re-ran the simulation and analyses using different discount factors. For our default discount of $20 \%$, we concluded that the lowest feasible return level for sustained compensation is $3.1 \%$. With discount of $10 \%$ it is $3.0 \%$ and with discount of $0 \%$, the result is $2.9 \%$. Thus, the overall effect of the discount factor is small.
} 
potential indirect agency costs from ex post opportunism. Therefore, the simulation results form a best case scenario assuming no moral hazard. In other words, the simulations produce upper boundaries of the levels of market failure that the different structures could correct via profit distribution at given gross return levels. It is also important to note that the simulation does not assume relationships between the distribution model and gross returns. The potential effects of distribution and compensation models on gross returns (e.g. self-selection influencing the quality of investors) are discussed in the conclusions section. ${ }^{16}$

The results of our simulation analyses for the interaction, and the limits to the LP and GP structures, are presented in Figure 5. The horizontal axis present the expected gross return of an alternative portfolio from a private sector fund, i.e. the opportunity cost of the GP and private LPs. The vertical axis presents the lowest feasible gross return level. The solid black lines report the lowest feasible expected gross returns from the portfolio for the analyzed profit distribution structures, given the costs of the GP's carry compensation required. That is, for the given opportunity cost, the lines present the lowest expected return levels at which the structures are able to maintain the same level of returns (for the private LPs) and compensation (for the GP) as the private actors receive. This analysis essentially incorporates the required carry ratios reported in Figure 4 to the distribution structures reported in Figure 2 in order to analyse their overall effect on the feasibility of structures.

Insert Figure 5 approximately here

The dashed gray line at an angle of $45^{\circ}$ presents the points where the opportunity cost and the lowest feasible return level are equal. Correspondingly, the area below the line marks the

\footnotetext{
${ }^{16}$ We thank an anonymous reviewer of paying attention to the importance of considering the effects of distribution and compensation models influencing the self selection and behaviour of investors with potentially significant effects on the performance of the funds. Given still relatively limited empirical research on the effects of the incentive structures in government sponsored venture capital funds on their gross IRR, we chose to not make assumptions on the magnitude of effects. Instead, our modelling provides the net returns in a range of gross returns allowing readers to easily test their own assumptions concerning the impacts of distribution structures on the gross returns (e.g. Figure 2).
} 
combinations where structures extend the participation to funds with return levels lower than the opportunity cost. Should the combination of opportunity cost and lowest feasible return levels fall below the line, then the structure does not offer means to increase the returns of private LPs in funds targeting markets with lower expected returns.. The examination is limited to the expected return levels above $5 \%$, since at this point, the compensation of the GP in the benchmark structure falls to zero. To compare these results with the earlier ones, the point A marks the benchmark opportunity cost and equals the lowest feasible return level. Point C (as in Figure 3 and in Figure 4) marks the lowest feasible level of portfolio return (3.1\%) for the benchmark of gross returns of $11.3 \%$.

Depending on the structure used, the incentives of the private LPs to participate are maintained with varying success. The asymmetric timing of the cash flows (LP 1) offers the greatest increase in the returns, thus allowing highest disparity between the opportunity cost and the lowest feasible gross return from the portfolio. Depending on the opportunity cost, this structure allows up to $9 \%$ lower expected gross returns compared to the opportunity cost. The loan structure (LP 2) and the structure where the profits of the public investor are capped (LP 3) produce more modest returns. They offer a higher increase in returns when the opportunity cost is high, and converge to the pari passu structure (that is, the dashed line) at the lower end of the opportunity costs. The guarantee structure (LP 4) does not offer any increased returns for the private LPs, as its returns coincide with those of the pari passu structure when the expected gross returns are non-negative.

The lowest, dashed line, presents the various combinations of the opportunity cost and the lowest feasible return level for the GP. It appears that at the return levels of our benchmark and above, the compensation of the GP is the least restricting element, as it allows the lowest feasible IRR from the portfolio. However, if the opportunity cost is lower than the benchmark, the compensation of the GP becomes the restricting condition if the structure of 
asymmetric timing is used for the profit distribution of LPs. While the asymmetric timing structure could maintain the returns of the private LPs also on lower return levels, the simultaneous compensation of the GP would require a carry ratio of over $100 \%$, thereby limiting the set of theoretically feasible return levels.

In total, it appears that depending on the opportunity costs of the private sector actors, the ability of the examined profit distribution and compensation structures to enhance the incentives of the GPs and LPs to participate is limited to modest levels of discrepancy in the expected gross returns. Furthermore, this enhancement in the returns is contingent on the structure used. Our simulations indicate that largest difference between the expected return from the opportunity cost and the targeted low return markets is approximately 9 percentage units, when the structure with asymmetric timing is used. Should the public investor decide to involve only private GPs to manage public funds but seek no investment from private LPs, the limitations are less severe at the higher end of the scale.

\section{Conclusions}

In this paper we set out to examine the characteristics and limitations of profit distribution and compensation structures targeted to attract private sector actors in publicly co-financed venture capital funds focusing on market failure areas. Prior research focusing on the same problem has relied primarily on case analysis (e.g. Gilson, 2003), providing deep insights but making it difficult to differentiate the specific characteristics of the structures from the idiosyncratic characteristics of the context in the case countries. In order to allow direct comparison and analysis of the profit distribution and compensation structures in a generic context, we have resorted to quantitative modelling and simulation. This allows us to directly compare the effects of alternative structures on our archetype early-stage VC fund.

In our stochastic simulation, we have used models based on existing profit distribution and compensation structures currently employed by governments. We find that, of the 
examined distribution structures, asymmetrically timed public and private investments offers the highest increase in the returns for the private LP after the direct costs of the compensation of the GP are subtracted. It therefore provides the most effective mechanism to skew the distribution of profits and thereby to create greater incentives for private investors to participate. Both of the structures, where public participation comes in the form of a loan or the returns of the public investor are capped, offer smaller increases in the returns for the LP. However, as their effect is most marked at higher performance levels, these profit distribution structures paradoxically only work in an environment where the need for asymmetric distribution is less pressing. The guarantee structure fails to increase the incentives to participate from the standard structure.

The compensation of the general partner, based a fixed share of capital gains, is similarly compromised when the market returns are significantly lower than the GP's opportunity cost. The carry mechanism offers only limited means to increase the compensation. When examining the conditions where both the LPs and GP have proper incentives to participate, we find, as expected, that the costs of increasing the compensation of the GP reduces the positive effect of profit distribution structures.

We also find that the conditions needed for the distribution and compensation structures to work for both LPs and the GP are rapidly compromised as the fund/portfolio performance reduces. Depending on the fund return levels pertaining in the fully commercial private equity/venture capital markets, the highest feasible difference to the expected returns of a publicly co-financed, hybrid venture capital fund is from 5 to 9 percentage units. We found that the only profit distribution structure that would attract private sector participation into challenging early-stage market segments, where such targeted funds are expected to produce returns significantly lower (i.e. less than 5\%, assuming opportunity cost of investing in the average fund of combined VC and PE market), is the asymmetric timing of the cash flows. 
The paper has important implications for the several governments presently enacting or considering various models of public support for venture capital activities in early-stage investments (see Table 1). Given that these distribution and compensation structures have been created to address the historically long run, low returns of specialist, early stage and new technology venture funds in VC markets (other than the US), the relatively low enhancements the structures are able to generate to returns and compensation are alarming. Although these structures can clearly boost the returns in conditions of a moderate market failure, they are of limited effectiveness in the most difficult and problematic areas unless these schemes also have the effect of improving the quality of investors and subsequent gross returns. As a consequence, governments will not be able to rely on such programmes alone to improve the supply of early-stage finance. They are likely to have to address other related issues, in particular improving the framework conditions that will encourage the participation of more skilled and experienced entrepreneurs in key technology sectors (Armour and Cumming, 2006; Da Rin et al, 2006; European Commission, 2005; HM Treasury and Small Business Service, 2001; OECD, 2004). ${ }^{17}$

Secondly, this finding suggests that it is extremely important to consider how such schemes could be designed to catalyze the involvement of more professional investors. ${ }^{18}$ This implication adds to the emerging literature supporting structures in government sponsored venture capital programs that reward good performance, i.e. promoting upside incentives,

$17 \quad$ For instance, based on an econometric analysis of the development of venture capital in 15 countries over a period of 14 years, Cumming and Armour (2006) conclude: "Generally, the results indicate the road to establishing Silicon Valley like equity market outside the US is paved with favourable tax laws and legal structures that accommodate the establishment of private equity funds, liberal bankruptcy laws that provide little or no time to discharge for entrepreneurs, and at most only a very small scope for direct government investment programs." Similarly, Da Rin et al. (2006) conclude based on their econometric analysis of the determinants of early stage venture capital: “...we believe our results have a clear message: sensible policy should consider a wider set of policies than simply channeling more funds into venture capital.” More specifically, they conclude: "we find that policies which increase the expected return of innovative projects are more successful in altering the composition of venture capital markets towards early stage projects and projects in high-tech industries."

$18 \quad$ For instance, current research (Zarutskie, 2006) tells that the most important success factor in first-time early stage venture capital funds is that the investment team includes both serial entrepreneur(s) and experienced venture capitalist(s). 
rather than protecting against losses via downside guarantees (Avnimelech and Teubal, 2006;

Gilson, 2003; Hirsch, 2006; Maula and Murray, 2003; Murray and Marriott, 1998).

We want to emphasise that our analyses are based on the distribution of given returns (for LPs) and expected compensation (for GP). Therefore, our analysis on the effects of the expected costs of the GP compensation on the LP returns (in section 4.3) is based on the direct costs of the GP compensation. That is, we do not include any indirect agency costs resulting from the GP’s ex post behaviour. Essentially, we make an assumption that should the performance be poor, and consequently, the expected compensation from the carried interested be lower than the ex ante expectation, the GP does not changes its effort allocation or risk taking over the life of the fund. While the legal agreements between general and limited partners as well as the adverse implications of fund failure on the venture capitalist's reputation usually tie the general partner to the fund for its duration, it is reasonable to assume in practice that the missing incentives are likely to affect the total effort contributed by the management. Any lessening of the GP's interest or commitment is likely to further adversely influence the fund's performance. Thus, in a sense, our results represent the best case scenario, where the GP continues to honour fully its duties regardless of its incentives. Any deterioration in the commitment and performance of the GP will exacerbate the scale of the problem the structures seek to address. How much do these agency concerns affect the performance of the funds and further deteriorate the effectiveness of the studied structures, is an interesting question for future research.

Two additional avenues for further research stem from the static nature of our treatise. First, we have started from the assumption that supporting the creation of new enterprises through private sector investors creates positive, indirect returns to the government (Achleitner and Klöckner, 2005; Alemany and Martí, 2005; BVCA, 2004a, 2004b; Engel and Keilbach, 2002; European Commission, 2003; EVCA, 2002; Kortum and Lerner, 2000; 
NVCA, 2002; Romain and van Pottelsberghe, 2004). Therefore, the redistribution of fund profits from the public to private sectors is believed to have a net public benefit over the longer term. However, there is still fairly limited research on the total economic and welfare effects of venture capital on the economy. Tracing these effects would require a dynamic approach to the consequences of government intervention on the venture capital industry. While existing research appears encouraging, it falls far short of quantifying these benefits. Therefore, a precise and credible assessment of the trade-offs between foregone returns and alternative, indirect benefits to the government investor, is problematic. The absence of a tested and robust, general evaluation methodology that can be used in assessing the multiple impacts of these fund leverage schemes for early-stage venture investments remains a serious and urgent shortcoming of contemporary policy decision making.

Second, focusing only on the characteristics of the distribution and compensation structures and their effect on expected returns for LPs and GP, we do not consider who will be attracted to manage or invest in these funds. With an unattractive risk reward trade-off, it is only the inexperienced and untested management teams that are prepared to pay this 'cost of entry' in order to become part of the VC industry. Additionally, down-side guarantees and upside incentives may have differential effects in attracting low and high quality GPs. While these assumptions appear valid, their testing and further elaboration requires further research.

\section{References}

Achleitner, A. K., Klöckner, O., 2005. Employment Contribution of Private Equity and Venture Capital in Europe. Center for Entrepreneurial and Financial Studies, Technische Universität München, Munchen, Germany.

Alemany, L., Martí, J., 2005. Unbiased estimation of economic impact of venture capital backed firms, (Paper presented at the European Financial Management Association 2006 Annual Meetings, June 28-July 1, 2006, Madrid, Spain).

Amit, R., Brander, J., Zott, C., 1998. Why do venture capital firms exist? Theory and Canadian evidence. Journal of Business Venturing, 13(6), 441-466.

Armour, J., Cumming, D. J., 2004. The legislative road to Silicon Valley, Oxford Economic Papers, 58(4), 596-635.

Avnimelech, G., Teubal, M. 2006., Creating venture capital industries that co-evolve with high tech: Insights from an extended industry life cycle perspective of the Israeli experience. Research Policy, 35, 1477-1498. 
Ayayi, A. 2004., Public policy and venture capital: The Canadian labor-sponsored venture capital funds. Journal of Small Business Management, 42(3), 335-345.

Barry, C. B., Muscarella, C. J., Peavy, J. W., Vetsuypens, M. R. 1990. The Role of Venture Capital in the Creation of Public Companies - Evidence from the Going-Public Process. Journal of Financial Economics, 27(2), 447-471.

Bergemann, D., Hege, U., 1998. Venture capital financing, moral hazard, and learning. Journal of Banking \& Finance, 22(6-8), 703-735.

Brophy, D. J., Haessler, M. R., 1994. Evaluating the Venture Capital Fund Agreement. Managerial Finance, 20(1), 53-64.

BVCA, 2004a., BVCA 2004 Agenda, British Venture Capital Association, London.

BVCA, 2004b., The Economic Impact of Private Equity in the UK 2003, British Venture Capital Association, London.

Cooper, I. A., Carleton, W. T., 1979. Dynamics of Borrower-Lender Interaction: Partitioning Final Payoff in Venture Capital Finance. Journal of Finance, 34(2), 517-529.

Cumming, D. J., MacIntosh, J. G., 2006. Crowding out private equity: Canadian evidence, Journal of Business Venturing, 21(5), 569-609.

Cumming, D. J., 2006., Government policy towards entrepreneurial finance: Innovation Investment Funds, Journal of Business Venturing, forthcoming.

Cressy, R. 2002., Funding gaps: A symposium. Economic Journal, 112(477), F1-F16.

Da Rin, M., Nicodano, G., Sembenelli, A., 2006. Public policy and the creation of active venture capital markets. Journal of Public Economics, 90(8-9), 1699-1723.

Dossani, R., Kenney, M., 2002. Creating an environment for venture capital in India. World Development, 30(2), 227-253.

Engel, D., Keilbach, M., 2002. Firm Level Implications of Early Stage Venture Capital Investment - An Empirical Investigation. Max Planck Institute for Research into Economic Systems, Jena, Germany.

European Commission, 2001. State aid and risk capital. Official Journal of the European Communities, 2001(C235), 3-11.

European Commission, 2003. Green Paper: Entrepreneurship in Europe, European Commission, Brussels.

European Commission, 2005. Best practices of public support for early-stage equity finance: Final report of the expert group. DG Enterprise and Industry. European Commission, Brussels.

EVCA, 2002. Survey of the Economic and Social Impact of Venture Capital in Europe, (Research Paper). The European Private Equity and Venture Capital Association (EVCA), Zaventem, Belgium.

EVCA, 2004. Benchmarking European Tax \& Legal Environments, European Private Equity and Venture Capital Association, Zaventum.

EVCA, 2005. Pan-European Survey of Performance - From Inception to 31 December 2004, European Private Equity and Venture Capital Association, Zaventum.

Fenn, G. W., Liang, N., Prowse, S., 1995. The Economics of the Private Equity Market. Federal Reserve System, Board of Governors, Washington DC.

Florida, R. L., Kenney, M., 1988. Venture Capital-Financed Innovation and TechnologicalChange in the USA. Research Policy, 17(3), 119-137.

Gilson, R. J., 2003. Engineering a venture capital market: Lessons from the American experience. Stanford Law Review, 55(4), 1067-1103.

Gompers, P., Lerner, J., 1996. The use of covenants: An empirical analysis of venture partnership agreements. Journal of Law \& Economics, 39(2), 463-498.

Gompers, P., Lerner, J., 1999. An analysis of compensation in the US venture capital partnership. Journal of Financial Economics, 51(1), 3-44.

Gompers, P. A., 1995. Optimal Investment, Monitoring, and the Staging of Venture Capital. Journal of Finance, 50(5), 1461-1489.

Hirsch, J., 2006. Public Policy and Venture Capital Financed Innovation: A Contract Design Approach, CFS Working Paper No. 2006/29.

HM Treasury \& Small Business Service, 2003. Bridging the finance gap: next steps in improving access to growth capital for small businesses, HM Treasury \& Small Business Service, London, UK. 
Kortum, S., Lerner, J. 2000. Assessing the contribution of venture capital to innovation. Rand Journal of Economics, 31(4), 674-692.

Leleux, B., Surlemont, B. 2003. Public versus private venture capital: seeding or crowding out? A pan-European analysis. Journal of Business Venturing, 18(1), 81-104.

Lerner, J. 1999. The government as venture capitalist: The long-run impact of the SBIR program. Journal of Business, 72(3), 285-318.

Lerner, J. 2002. When bureaucrats meet entrepreneurs: The design of effective 'public venture capital' programmes. Economic Journal, 112(477), F73-F84.

Lerner, J., Moore, D., Shepherd, S., 2005 A study of New Zealand's venture capital market and implications for public policy: Report to the Ministry of Research Science and Technology. LECG Limited, Auckland.

Litvak, K., 2004. Venture Capital Limited Partnership Agreements: Understanding Compensation Arrangements. University of Texas School of Law.

Maula, M. V. J., Murray, G. C., 2003. Finnish Industry Investment Ltd: An International Evaluation, (Publications 1/2003). Ministry of Trade and Industry, Helsinki.

Megginson, W. L., Weiss, K. A., 1991. Venture Capitalist Certification in Initial Public Offerings. Journal of Finance, 46(3), 879-903.

Modena, V (ed.), 2002. Israeli Financing Innovation Schemes for Europe: Final Report. University of Pavia The University-Enterprise Liaison Office

Murray, G. C., 1998. A policy response to regional disparities in the supply of risk capital to new technology based firms in the european union: The european seed capital fund scheme. Regional Studies, 32(5): 405-419.

Murray, G. C., Marriott, R., 1998. Why has the investment performance of technologyspecialist, European venture capital funds been so poor? Research Policy, 27(9), 947-976.

NVCA, 2002. The Economic Impact of the Venture Capital Industry on the U.S. Economy, (study conducted by DRI-WEFA for NVCA). National Venture Capital Association, Arlington, VA.

OECD, 1997. Government Venture Capital for Technology-Based Firms, (OCDE/GD(97)201). Organization for Economic Co-operation and Development, Paris.

OECD, 2004. Venture Capital: Trends and Policy Recommendations, Organisation for Economic Co-operation and Development, Paris.

OECD. 2006. OECD Keynote Paper for SME Financing Gap: Theory \& Evidence. Organisation for Economic Co-operation and Development, Paris.

Romain, A., van Pottelsberghe, B., 2004. The Economic Impact of Venture Capital. Discussion Paper Series 1: Studies of the Economic Research Centre No 18/2004, Deutsche Bundesbank.

Sahlman, W. A., 1990. The Structure and Governance of Venture-Capital Organizations. Journal of Financial Economics, 27(2), 473-521.

Schmidt, D., Wahrenburg, M., 2003. Contractual relations between European VC Funds and investors: The impact of Bargaining power and reputation on contractual design. CFS Working Paper No. 2003/15.

US Small Business Administration, 2003. Small Business Investment Company Report Fiscal Year 2002 Special Report, Small Business Administration, Washington D.C.

Wessner, C. W. (Ed.), 2002. Government-industry partnerships for development of new technologies. National Research Council, Washington DC.

Williams, P., 1998. Financing the High Technology Business; A report to the Paymaster General, HM Treasury, London.

Wright, M., Robbie, K., 1998. Venture Capital and Private Equity: A Review and Synthesis. Journal of Business Finance and Accounting, 25(5-6), 521-570.

Zarutskie, R., 2006. Do Venture Capitalists Affect Investment Performance? Evidence from First-Time Funds. Paper accepted to be presented at the American Finance Association Meeting, Chicago, 2007.

Zider, B., 1998. How venture capital works. Harvard Business Review, November-December, 131-139. 
Table 1 Examples of existing profit distribution structures in government supported venture capital funds

\begin{tabular}{|c|c|c|c|c|}
\hline Feature & Description & Profit distribution effects & $\begin{array}{l}\text { Examples (present \& } \\
\text { past) }\end{array}$ & $\begin{array}{l}\text { Category based } \\
\text { on effects on } \\
\text { profit distribution }\end{array}$ \\
\hline $\begin{array}{l}\text { Public } \\
\text { investor co- } \\
\text { investing } \\
\text { with private } \\
\text { investors }\end{array}$ & $\begin{array}{l}\text { Government } \\
\text { matching the } \\
\text { investments by } \\
\text { private investors }\end{array}$ & $\begin{array}{l}\text { Helps in setting up a fund. Also helps to } \\
\text { build a sufficiently big fund to benefit from } \\
\text { economies of scale. } \\
\text { Investing in pari passu with private } \\
\text { investors does not have direct profit } \\
\text { distribution effects. }\end{array}$ & $\begin{array}{l}\text { Public participation } \\
<50 \% \text { of the fund: } \\
\text { Europe/EIF } \\
\text { Finland/FII } \\
\text { Israel/Yozma } \\
>50 \% \text { of the fund: } \\
\text { Australia/IIF and } \\
\text { Pre-seed Fund } \\
\text { USA/SBIC and } \\
\text { SSBIC } \\
\text { UK/regional venture } \\
\text { capital funds }\end{array}$ & Pari Passu \\
\hline $\begin{array}{l}\text { Timing of } \\
\text { cash flows }\end{array}$ & $\begin{array}{l}\text { Ordering of the cash } \\
\text { flows so that public } \\
\text { investor puts the } \\
\text { money in first and } \\
\text { gets the money out } \\
\text { last }\end{array}$ & $\begin{array}{l}\text { The IRR of the private investor can be } \\
\text { enhanced through timing of cash flows } \\
\text { improving the attractiveness of the fund. }\end{array}$ & $\begin{array}{l}\text { UK / Regional Venture } \\
\text { Capital Funds }\end{array}$ & $\begin{array}{l}\text { Differential timing } \\
\text { of the investment } \\
\text { of public and } \\
\text { private investors }\end{array}$ \\
\hline $\begin{array}{l}\text { Public } \\
\text { participation } \\
\text { as a loan }\end{array}$ & $\begin{array}{l}\text { Government } \\
\text { provides its share of } \\
\text { capital as a loan } \\
\text { with interest }\end{array}$ & $\begin{array}{l}\text { The loan with interest creates a leverage } \\
\text { effect on the return of private investor when } \\
\text { the returns from the fund exceed the interest } \\
\text { rate. Correspondingly, losses are increased } \\
\text { with low performance. }\end{array}$ & $\begin{array}{l}\text { USA/SBIC } \\
\mathrm{UK} / \mathrm{ECF}\end{array}$ & $\begin{array}{l}\text { Leveraging the } \\
\text { returns to private } \\
\text { investors with a } \\
\text { loan }\end{array}$ \\
\hline $\begin{array}{l}\text { Capped } \\
\text { return for } \\
\text { public } \\
\text { investors }\end{array}$ & $\begin{array}{l}\text { After the all the } \\
\text { investors (including } \\
\text { the public investor) } \\
\text { have received } \\
\text { certain IRR, the rest } \\
\text { of the cash flows are } \\
\text { distributed to private } \\
\text { investors only. }\end{array}$ & $\begin{array}{l}\text { Capped return for the government increases } \\
\text { the expected IRR for private investors. This } \\
\text { distribution increases the compensation for } \\
\text { good performance. This in turn creates a } \\
\text { strong incentive for the private investors to } \\
\text { incentivise the general partners to make } \\
\text { successful investments and add value to } \\
\text { portfolio companies }\end{array}$ & $\begin{array}{l}\text { UK/regional venture } \\
\quad \text { capital funds } \\
\text { Australia/Pre-seed fund } \\
\text { Chile/CORFU }\end{array}$ & $\begin{array}{l}\text { Limiting the } \\
\text { profits entitlement } \\
\text { of the public } \\
\text { investor }\end{array}$ \\
\hline $\begin{array}{l}\text { Buy-put } \\
\text { option for } \\
\text { private } \\
\text { investors. }\end{array}$ & $\begin{array}{l}\text { Private investors are } \\
\text { given the option to } \\
\text { buy the share of the } \\
\text { government at (or } \\
\text { until) a specific } \\
\text { point of time at } \\
\text { predetermined price } \\
\text { (typically nominal } \\
\text { price + interest) }\end{array}$ & $\begin{array}{l}\text { The effects on the IRR of private LP are } \\
\text { similar to the "capped return” structure. } \\
\text { However, there are two additional benefits: } \\
\text { 1) The buy-out option gives both the public } \\
\text { and the private LP an opportunity to } \\
\text { demonstrate success earlier and more } \\
\text { visibly than in the capped return alternative } \\
\text { 2) In the case of success, government gets a } \\
\text { quick exit from the fund and can reinvest } \\
\text { the money instead of waiting for the returns } \\
\text { on fund termination }\end{array}$ & $\begin{array}{l}\text { Israel / Yozma } \\
\text { New Zealand / New } \\
\text { Zealand Venture } \\
\text { Investment Fund }\end{array}$ & \\
\hline $\begin{array}{l}\text { Downside } \\
\text { protection }\end{array}$ & $\begin{array}{l}\text { Downside protection } \\
\text { means the } \\
\text { government } \\
\text { underwriting losses } \\
\text { from the portfolio. }\end{array}$ & $\begin{array}{l}\text { Downside protection helps support the IRR, } \\
\text { when partial loss of invested capital is } \\
\text { probable. }\end{array}$ & $\begin{array}{l}\text { Germany / WFG } \\
\text { Germany / tbg \& KfW } \\
\text { France / SOFARIS } \\
\text { Denmark/ The Equity } \\
\quad \text { Guarantee } \\
\quad \text { Programme }\end{array}$ & $\begin{array}{l}\text { Guarantee of } \\
\text { compensation to } \\
\text { the private } \\
\text { investor for loss of } \\
\text { invested capital }\end{array}$ \\
\hline $\begin{array}{l}\text { Fund } \\
\text { operating } \\
\text { costs }\end{array}$ & $\begin{array}{l}\text { Government } \\
\text { subsidises the } \\
\text { management } \\
\text { company to cover } \\
\text { some of the costs } \\
\text { from running the } \\
\text { fund. }\end{array}$ & $\begin{array}{l}\text { Subsidies create an effect similar to the } \\
\text { structure with asymmetric timing of cash } \\
\text { flows. Magnitude of the effect depends on } \\
\text { the size of subsidy. }\end{array}$ & $\begin{array}{l}\text { Europe / European Seed } \\
\text { Capital Scheme }\end{array}$ & (Not examined) \\
\hline
\end{tabular}


Figure 1 Generic Model of an 'Equity Enhancement' Program based on SBIC

Figure based on UK's Small Business Service presentation on proposed Enterprise Capital Funds, 2004

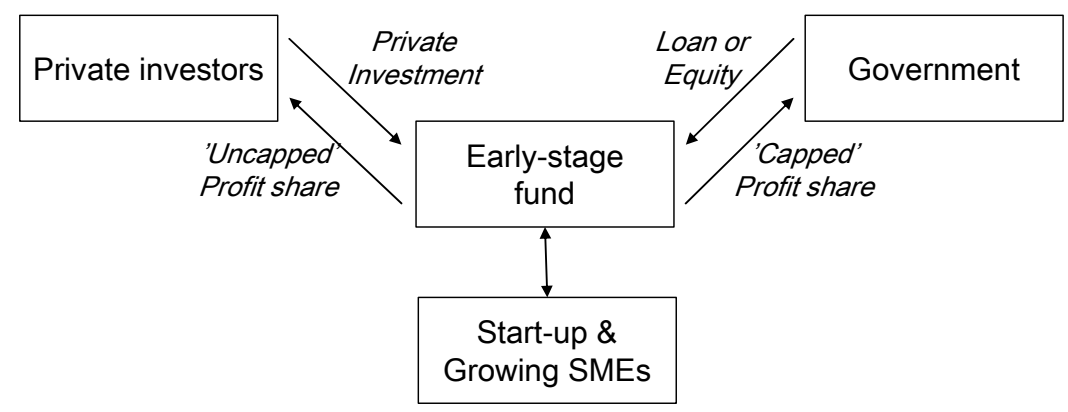


Table 2 The parameters of the simulation model

\begin{tabular}{|c|c|c|c|c|c|c|c|}
\hline \multicolumn{4}{|l|}{ Fund } & \multicolumn{4}{|l|}{ Investors } \\
\hline \multicolumn{3}{|l|}{ Lifetime } & 10 years & \multicolumn{3}{|c|}{ Share of governmental investor } & $49.5 \%$ \\
\hline \multicolumn{3}{|l|}{ Investment window } & 4 years & \multicolumn{3}{|c|}{ Share of private investors } & $49.5 \%$ \\
\hline \multicolumn{3}{|c|}{ Number of investment targets } & 15 & \multicolumn{3}{|c|}{ Share of general partner } & $1 \%$ \\
\hline \multicolumn{3}{|c|}{ Number of rounds per investment } & 3 & & & & \\
\hline \multicolumn{3}{|l|}{ Round interval } & 2 years & & & & \\
\hline \multicolumn{3}{|l|}{ Investment arrival } & lly spaced & & & & \\
\hline \multicolumn{8}{|l|}{ Scenarios } \\
\hline Multiples & round 1 & round 2 & round 3 & Probabilities & round 1 & round 2 & round 3 \\
\hline outcome 1 & 0.2 & 0.2 & 0.5 & outcome 1 & $10 \%$ & $10 \%$ & $10 \%$ \\
\hline outcome 2 & 0.5 & 0.75 & 1.5 & outcome 2 & $40 \%$ & $40 \%$ & $40 \%$ \\
\hline outcome 3 & 1.5 & 2.0 & 3.0 & outcome 3 & $40 \%$ & $40 \%$ & $40 \%$ \\
\hline outcome 4 & 2.5 & 3.0 & 4.0 & outcome 4 & $10 \%$ & $10 \%$ & $10 \%$ \\
\hline
\end{tabular}


Table 3 The tested profit distribution and compensation structures of limited and general partners.

\section{Profit distribution structures}

(benchmark model)

Government invests first

(LP structure 1)

Government loan investment

(LP structure 2)

Government return capped

(LP structure 3)

Downside guarantee

(LP structure 4)

The standard venture capital fund structure where LPs invest on equal terms (pari passu) with no distinction between private and public investors.

The public investor's committed capital is fully drawn down before calls on the private LPs.

Government's investment is made as loan. Effectively, the government has preferred fixed return of $5 \%$ on its invested capital.

The returns of the public LP are limited to a predetermined level of 5\%, and the remaining profits are distributed only to the private LPs and the GP.

The governmental investor provides a guarantee for private investors, which covers $75 \%$ of the project investment losses of private LPs including the GP's capital contribution to the fund.

\section{Components of general partner's compensation}

Fee income

Carried interest

Hurdle rate

Catch-up
General partner takes an annual charge of $2.5 \%$ on the total LP funds committed

General partner's share of the net capital gains exceeding hurdle rate. Benchmark value is $20 \%$.

Rate defining the return level on the committed capital after which the profits are considered net capital gain, subject to carry. Benchmark is set at $5 \%$

After hurdle is met, there may be a catch-up period during which the net capital gains are directed solely to general partner until it has received the carried interest of $20 \%$. After this ratio is achieved, future profits are distributed 20/80 between general and limited partners. 
Figure 2 Median returns for the private and public investors (limited partners) at different levels of portfolio return.

The solid line presents the returns to private investors and the dashed line to the public investor. Dotted lines present the 25th and 75th percentile of the returns. For the comparison, the returns of the pari passu model are presented in grey. In each chart, horizontal axis presents the IRR from the portfolio, and vertical axis the IRR of investors.
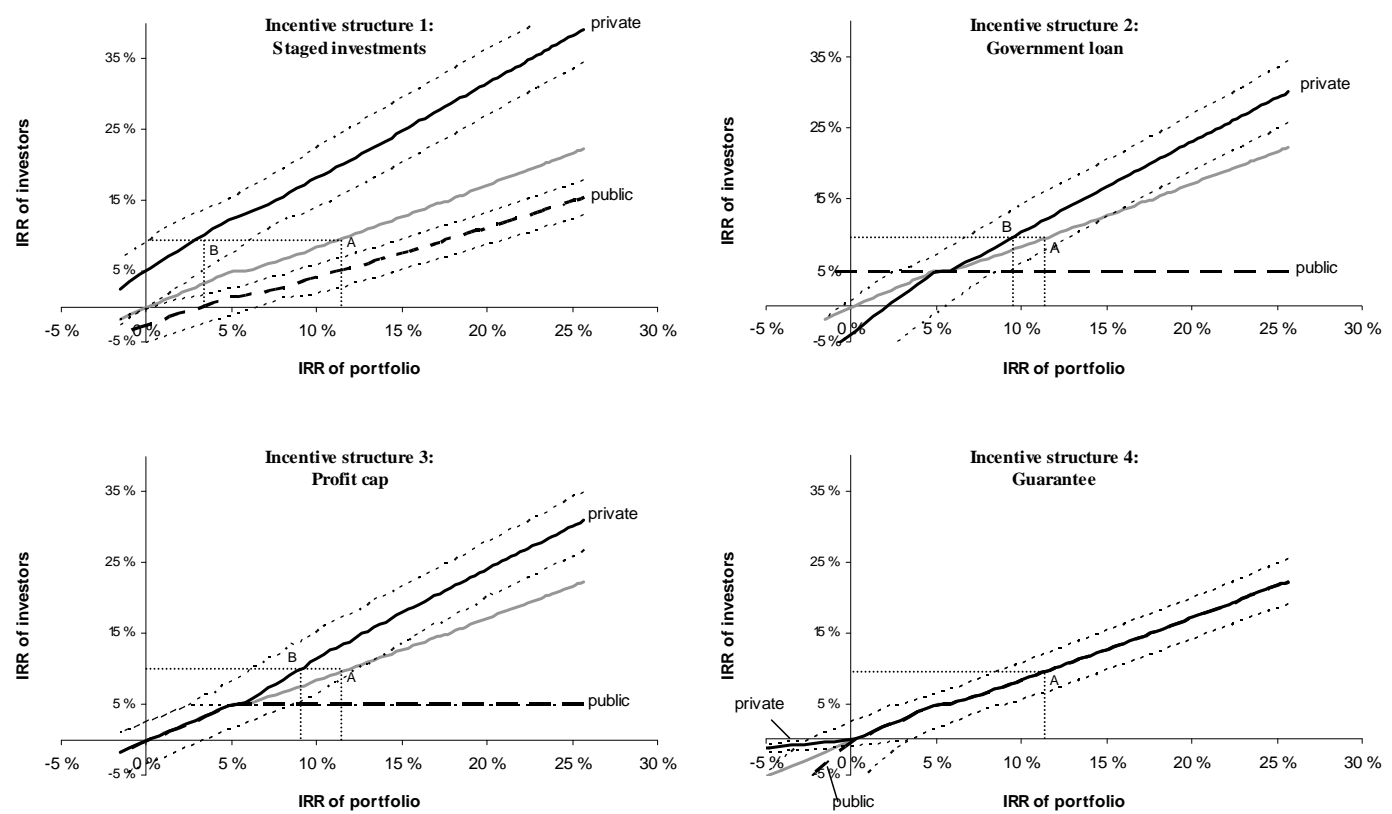
Figure 3 General partner’s expected compensation under different compensation structures. Point A marks the benchmark compensation of the general partner. Point B denotes the enhancement in compensation, when the hurdle rate is removed from the compensation structure. Point $\mathrm{C}$ is the lowest possible market level at which the benchmark compensation is available to the general partner. At this point the level of carry is $100 \%$, i.e. all profits are distributed to general partner.

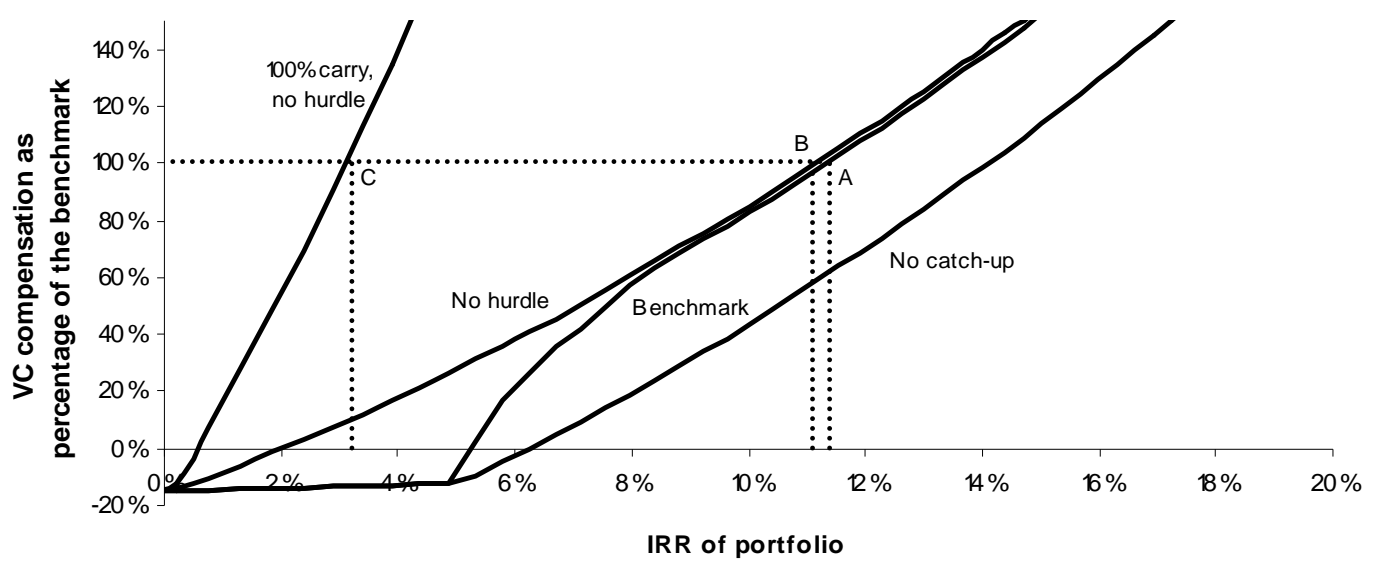


Figure 4 The carried interest levels that hold the general partner's compensation constant under different levels of portfolio performance.

The curves mark the indifference lines, where the compensation of the GP is constant. Lowering expected portfolio return requires higher carry to hold the compensation level constant. White circles mark the benchmark opportunity cost, when the GP receives a carry of $20 \%$ with catch-up, after meeting a hurdle of $5 \%$. The numbers next to circles mark the opportunity cost of each curve.

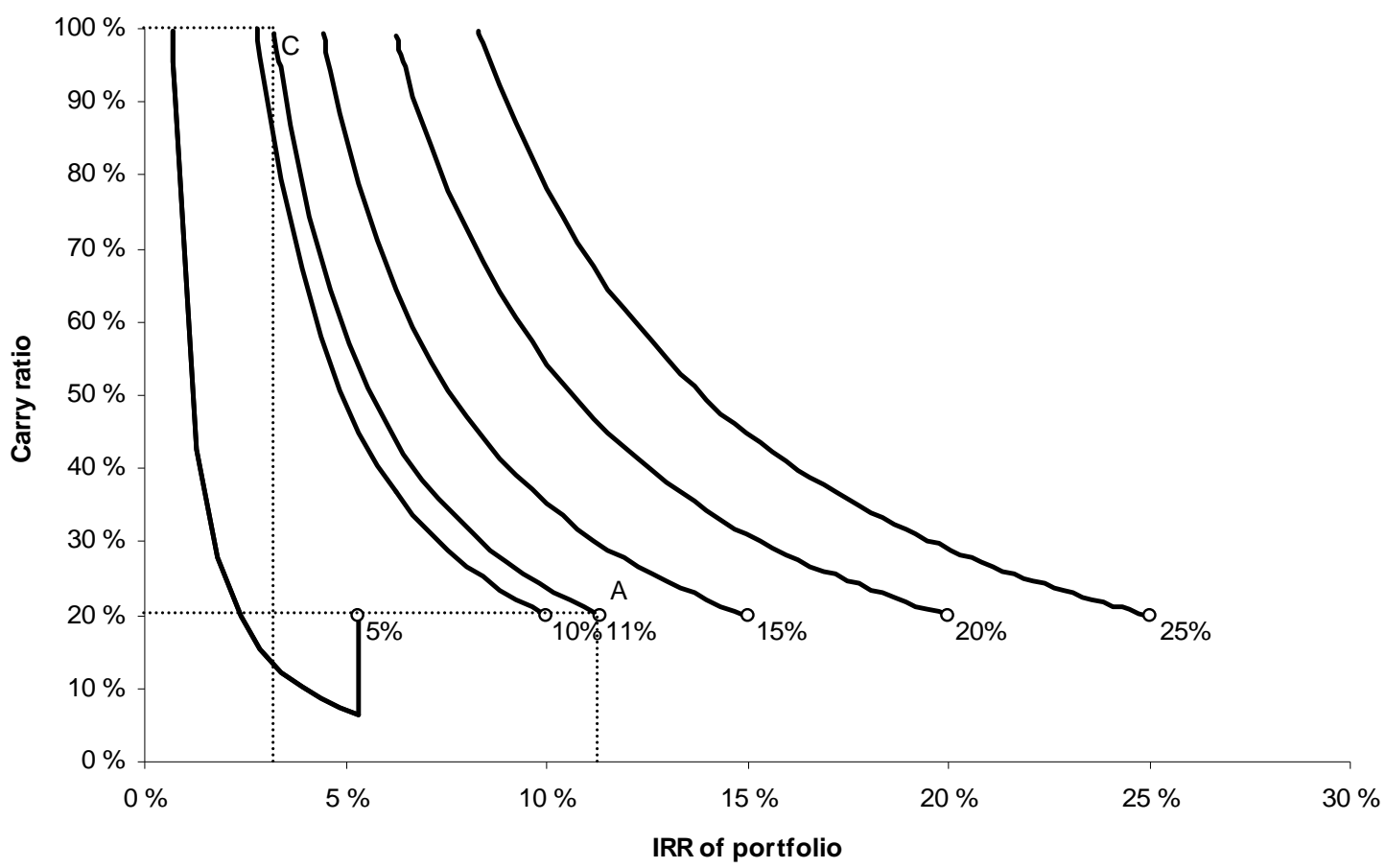


Figure 5 Lowest feasible portfolio returns for LP and GP fund involvement at given opportunity costs

The solid lines present the combinations of opportunity costs and the matching lowest feasible return level for the private LPs using different distribution structures. Dashed black line presents the same analysis for the GP. Dashed grey line presents the points where opportunity cost and lowest feasible return level are equal.

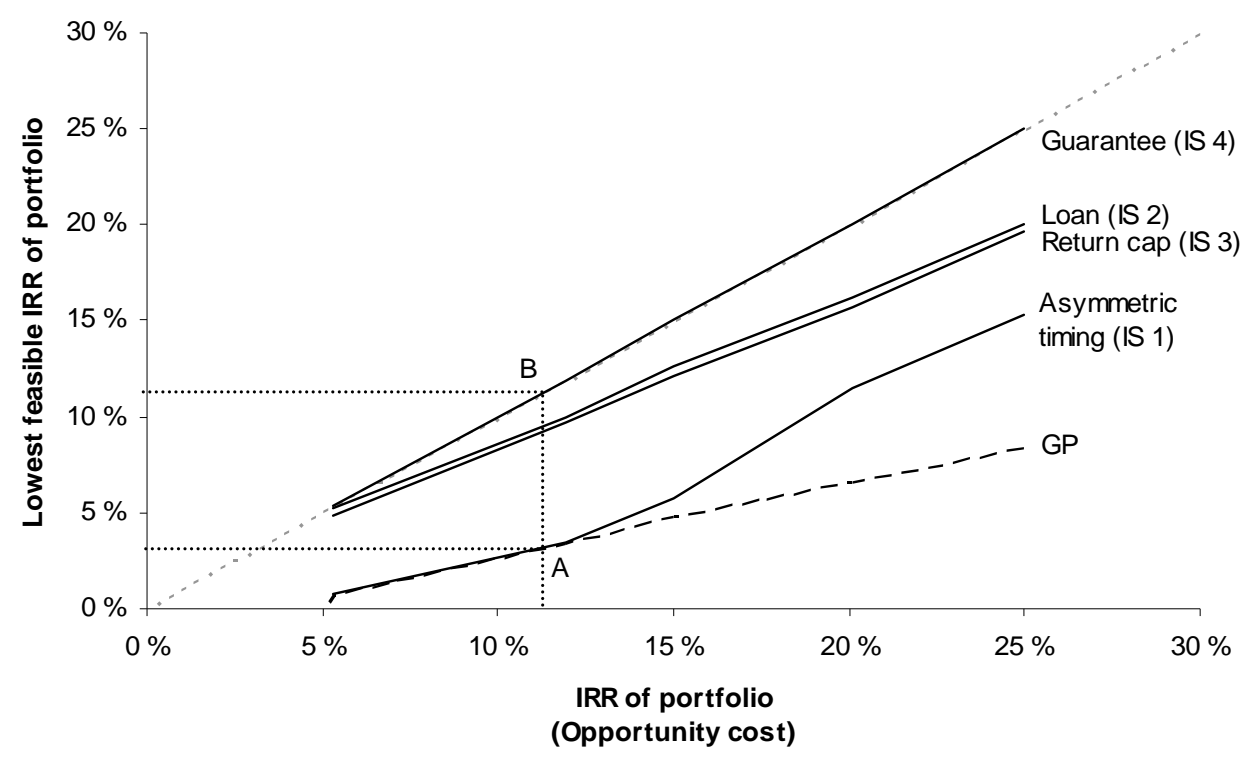

